\title{
Quantitative reconstruction of climatic variations during the Bronze and early Iron ages based on pollen and lake-level data in the NW Alps, France
}

- M. Magny ${ }^{\mathrm{a}}$,

- O. Peyron ${ }^{\mathrm{a}}$

- E. Gauthier ${ }^{\mathrm{a}}$

- Y. Rouèche ${ }^{\mathrm{a}}$

- A. Bordon ${ }^{\mathrm{a}}$

- Y. Billaud ${ }^{b}$

- E. Chapron ${ }^{\mathrm{c}}$

- A. Marguet ${ }^{b}$

- P. Pétrequin ${ }^{\mathrm{a}}$

- B. Vannière ${ }^{\mathrm{a}}$

- $\quad{ }^{a}$ Faculté des Sciences et Techniques, Laboratoire de Chrono-Ecologie, UMR 6565 du CNRS, 16 Route de Gray, 25030 Besançon, France

- ${ }^{\mathrm{b}}$ DRASSM, 58 bis Avenue des Marquisats, 74000 Annecy, France

- ${ }^{\mathrm{c}}$ Geological Institute, ETH Zürich, Universtätstrasse 16, CH-8092 Zürich, Switzerland

\begin{abstract}
Vegetation and lake-level data from the archaeological site of Tresserve, on the eastern shore of Lake Le Bourget (Savoie, France), are used to provide quantitative estimates of climatic variables over the period 4000-2300 cal BP in the northern French Pre-Alps, and to examine the possible impact of climatic changes on societies of the Bronze and early Iron Ages. The results obtained indicate that phases of higher lake level at 3500-3100 and 2750-2350 cal BP coincided with major climate reversals in the North Atlantic area. In west-central Europe, they were marked by cooler and wetter conditions. These two successive events may have affected ancient agricultural communities in west-central Europe by provoking harvest failures, more particularly due to increasing precipitation during the growing season. However, archaeological data in the region of Franche-Comté (Jura Mountains, eastern France) show a general expansion of population density from the middle Bronze Age to the early Iron Age. This suggests a relative emancipation of proto-historic societies from climatic conditions, probably in relation to the spread of new modes of social and economic organisation.
\end{abstract}

\section{Introduction}

In addition to influences of climatic variations, the evolution of the environment during the second half of the Holocene appears to be characterised by an increasing impact of human societies on natural landscapes. After the expansion of a new subsistence strategy based on farming and animal breeding during the Neolithic, the diffusion of the metallurgy and its associated technological efficiency marks a second step towards a possible increase in anthropogenic disturbances of the natural environment. However, despite this general context of economic and technical advances, recent investigations have suggested that Bronze Age societies in Central Europe were relatively sensitive to the climatic variations which punctuated the late Holocene (Tinner et al., 2003; Zolitschka et al., 2003). In the middle 20th century, German archaeologists pointed to apparent synchronisms between a climatic reversal 
at the Subboreal-Subatlantic transition and the cultural transition from the Bronze to the Iron Ages (Smolla, 1954; see also Millotte, 1963 and references therein). The general abandonment of lake-dwellings during the middle and at the end of Bronze Age to the north of the Alps (Magny, 1993) appears as another print of climate on Bronze Ages societies. This may support the hypothesis of possible strong influences of climatic conditions on human cultural evolution during protohistoric times in Western Europe.

However, while multiple Holocene climate records have been established in Central Europe from various archives (Haas et al., 1998; Schmidt et al., 2002; Heiri et al., 2003; Zolitschka et al., 2003; Magny, 2004; Nicolussi et al., 2005), quantitative reconstructions of seasonal changes in both temperature and precipitation are still rare. However, such seasonally resolved quantitative records are nevertheless needed for a better understanding of possible links between variations in the climate and the history of societies during the Bronze and early Iron Ages. As a contribution to these quantitative investigations, this paper presents a reconstruction of temperature and precipitation changes based on the modern analogue method using both pollen and lake-level data obtained at Tresserve, an archaeological site on the south-eastern shore of Lake Le Bourget in the northern French Pre-Alps.

\section{Study site and methods}

Lake Le Bourget $\left(45^{\circ} 45^{\prime} \mathrm{N}-5^{\circ} 55^{\prime} \mathrm{E}\right)$ is a 18 -km-long narrow and over-deepened basin of glacial origin. It is located at an altitude of $231.5 \mathrm{~m}$ in the northern French Pre-Alps (Fig. 1). The lake area is ca. $44.6 \mathrm{~km}^{2}$ and the maximum depth reaches $150 \mathrm{~m}$. Its catchment area covers $550 \mathrm{~km}^{2}$ with a maximal elevation at $1845 \mathrm{~m}$ a.s.l. However, during major flooding events of the Rhone River (a catchment of $4000 \mathrm{~km}^{2}$ culminating at $4807 \mathrm{~m}$ a.s.1.), the outlet of the lake functioned as an inlet and sometimes provoked catastrophic flooding before recent arrangements to regulate lake-level fluctuations (Chapron et al., 2005). The lake is fed by seasonal rain and snow melting. The climate of the area can be defined as temperate. The mean annual temperature is ca. $12{ }^{\circ} \mathrm{C}$, in the coldest month $3{ }^{\circ} \mathrm{C}$ and in the warmest month $21{ }^{\circ} \mathrm{C}$. Annual precipitation reaches ca. $1150 \mathrm{~mm}$. Deciduous forests with Alnus, Quercus and Corylus dominate areas below $700 \mathrm{~m}$ a.s.1., while Fagus and Abies dominate the montane belt (700-1500 m a.s.1.). Picea abies and Pinus uncinata characterise the subalpine forests above $1500 \mathrm{~m}$ a.s.l. The Holocene deposits of Lake Le Bourget are mainly composed of sand (detrital input from the catchment area) and authigenic carbonate lake marl.

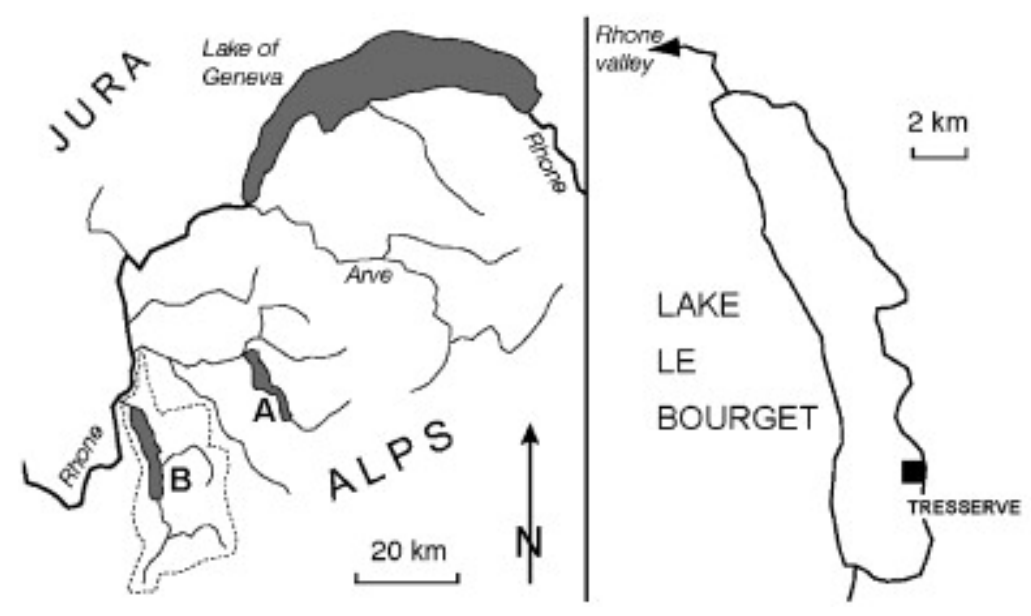


Fig. 1. Geographical location of site Tresserve, Lake Le Bourget, in the north-western French Pre-Alps. Broken line: catchment area of Lake Le Bourget without flooding from the Rhone river: (A) Lake Annecy, (B) Lake Le Bourget.

Recent subaquatic archaeological investigations at Tresserve, on the littoral platform along the south-eastern shore of the lake have discovered remains of late Bronze Age lake-dwellings (Marguet, 1995; Marguet and Billaud, 1997; Billaud, 2006; Billaud and Marguet, 2006). The chronology is based on (AMS) radiocarbon dates from terrestrial plant macrofossils and on tree-ring dates from wooden posts found in archaeological layers and corresponding to parts of Bronze Age houses. The radiocarbon dates were calibrated using IntCal 5 (Stuiver et al., 1998). Cores have been taken for pollen and sediment analysis. This paper presents results obtained from core 5 (Fig. 2).

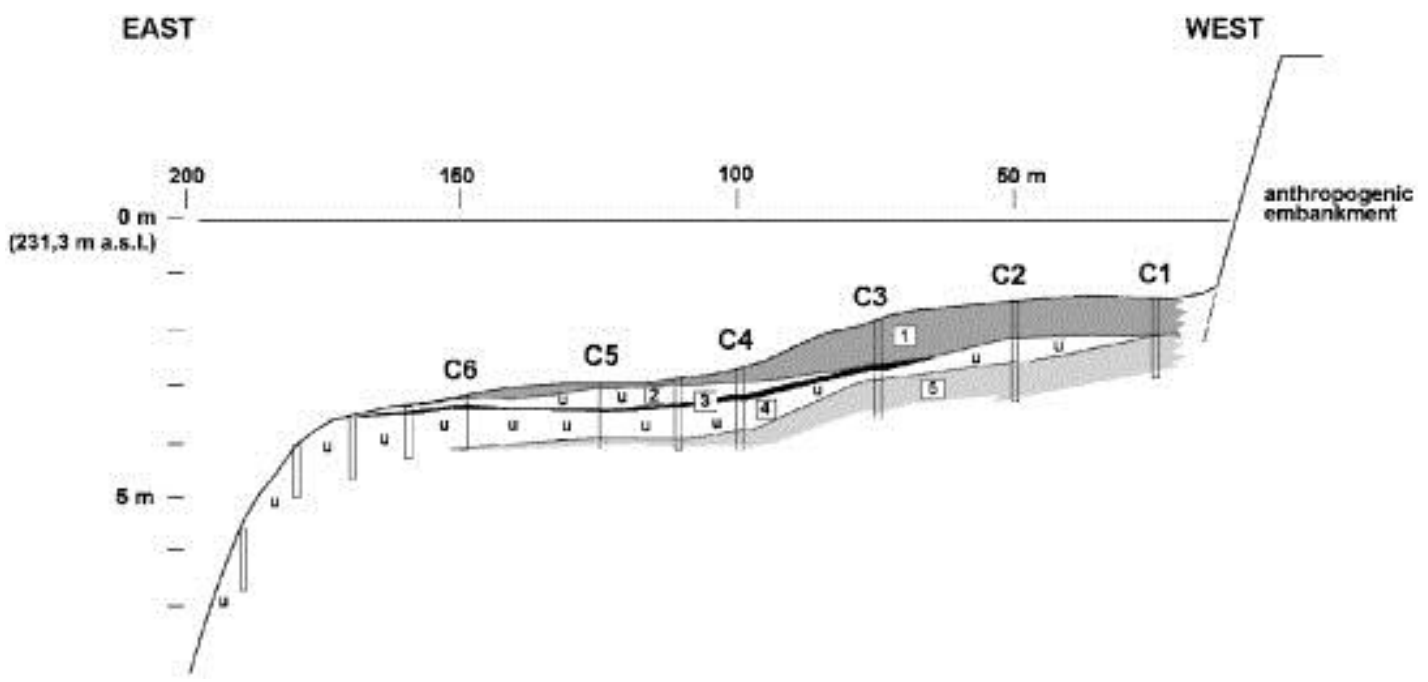

Fig. 2. Stratigraphic section established at Tresserve with the location of cores 5 and 6. The vertical bars correspond to sediment cores.

Samples for pollen analysis were treated by acetolysis and $\mathrm{HCl}$. They show excellent preservation and high concentration of pollen and spores. Usually, a sum of at least 500 pollen grains was counted in each sample. The results of the counts are presented in a simplified percentage pollen diagram (Fig. 3). All arboreal and non-arboreal pollen is included in the basic pollen sum, while spores are excluded. 


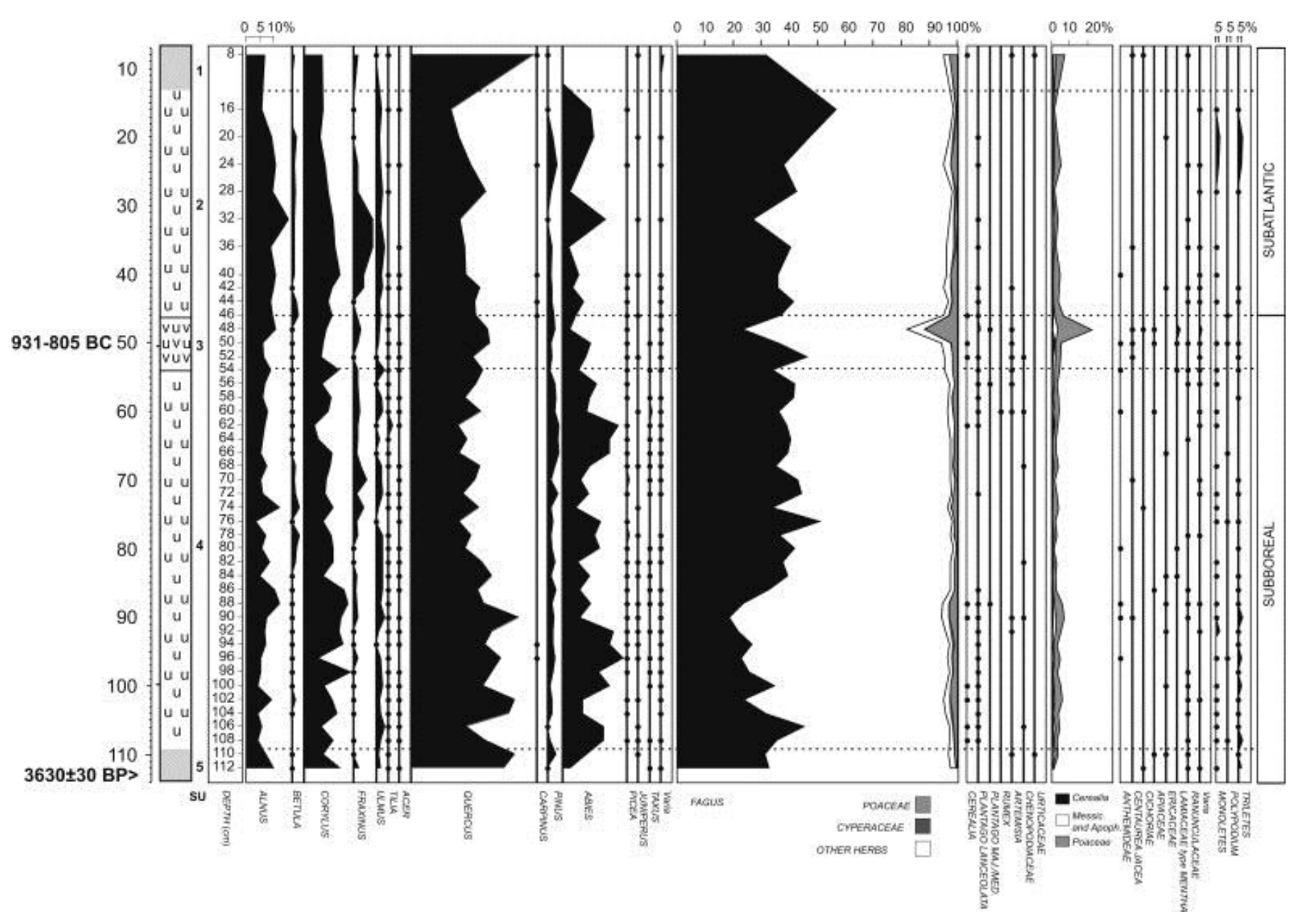

Fig. 3. Simplified pollen diagram of core 5. SU: sediment units.

The lake-level fluctuations were reconstructed using a specific method developed by Magny, 1998, Magny, 2004 and Magny, 2006. It is based on multiple lines of evidence, including changes in sediment texture, lithology, and the relative frequency of various carbonate concretion morphotypes of biochemical origin. Each morphotype shows a specific spatial distribution from the shore to the extremity of the littoral platform, with the successive domination of oncolites (nearshore areas with shallow water and high-energy environment), cauliflower-like forms (littoral platform), plate-like concretions (encrustations of leaves from the Potamogetonion and Nymphaeion belts), and finally tube-like concretions (stem encrustations from the Characeae belt on the platform slope). The reconstruction of a curve of relative changes in lake level is based on the ratio between the total scores of indicators of low lake-level conditions (e.g. oncolites, cauliflower-type carbonate concretions) and those of high lake-level conditions (e.g. plates and tubes) (Magny, 2006).

The quantitative estimate of climatic parameters from pollen and lake-level data is based on a model developed by Guiot et al. (1993) and Cheddadi et al. (1997) to refine the palaeoclimatic reconstruction based only on pollen data. The method has been extensively described in Magny et al. (2001). The principle is to find, for each fossil pollen assemblage, several similar modern pollen spectra (modern analogues). This approach relies on the degree of similarity (or distance) between fossil assemblages and spectra from a modern reference pollen data base, including more than 1300 European surface pollen samples from which 8-10 modern 
analogues are selected. The climate of these analogues is averaged to provide an estimate of the fossil assemblage climate.

However, problems arise when reconstructing past precipitation because, in Europe, the moisture of the growing season is rarely the main limiting factor for vegetation on a regional scale and modern analogues tend to span a wide range of precipitation estimates. As pointed out by Guiot et al. (1993), lake-level records can provide a complementary source of information on precipitation changes. They offer an additional constraint for pollen-based quantitative reconstruction of climatic parameters. Analogues giving a climate that was incompatible with the lake-level status were rejected. Thus, the climate reconstruction is based only on those analogues coherent with lake levels (Guiot et al., 1993).

\section{Results}

Fig. 2 presents the sediment sequence observed at Tresserve. Five main lithological units may be distinguished.

At the top, a sand layer (unit 1). This corresponds to detritic input associated to medieval and modern anthropogenic deforestation of surrounding areas, and/or perturbations in sedimentation linked to recent regulation of lake level.

Two carbonate lake-marl layers (units 2 and 4) separated by an anthropogenic organic layer (unit 3) composed of the remains of a late Bronze Age village tree-ring dated to 931-805 BC. The lower part of unit 4 in cores 3 and 1 has been radiocarbon dated to $3475 \pm 50$ and $3450 \pm 45$ BP, respectively (Table 1, Fig. 2). 
Table 1. Radiocarbon dates obtained from the sediment sequence of Tresserve

\begin{tabular}{|c|c|c|c|c|c|c|}
\hline Core & $\begin{array}{l}\text { Sediment } \\
\text { unit }\end{array}$ & $\begin{array}{l}\text { Tree-ring (in BC) } \\
\text { radiocarbon (in BP) } \\
\text { age }\end{array}$ & $\begin{array}{c}\text { Calibrated age } \\
\text { (1 sigma) }\end{array}$ & $\begin{array}{c}\text { Calibrated age } \\
\text { (2 sigmas) }\end{array}$ & Laboratory & Material \\
\hline $\begin{array}{l}\text { Core } 5 \text { (47- } \\
54 \mathrm{~cm})\end{array}$ & US 3 & $931-805$ BC & & & Archeolabs & \\
\hline Core 3 & US 4 & $3450 \pm 45$ BP & $\begin{array}{l}1875-169 \mathrm{cal} \\
\mathrm{BC}\end{array}$ & $\begin{array}{l}1883-1637 \mathrm{cal} \\
\text { BC }\end{array}$ & ARC 2236 & Wood \\
\hline Core 1 & US 4 & $3475 \pm 50$ BP & $\begin{array}{l}1880-1693 \mathrm{cal} \\
\text { BC }\end{array}$ & $\begin{array}{l}1920-1644 \mathrm{cal} \\
\text { BC }\end{array}$ & ARC 2238 & Wood \\
\hline $\begin{array}{l}\text { Core } 5 \\
(112 \mathrm{~cm})\end{array}$ & US 5 & $3630 \pm 30 \mathrm{BP}$ & $\begin{array}{l}\text { 2031-1942 cal } \\
\text { BC }\end{array}$ & $\begin{array}{l}2127-1888 \mathrm{cal} \\
\mathrm{BC}\end{array}$ & VERA 2760 & Twig \\
\hline
\end{tabular}

Radiocarbon ages have been calibrated using Calib.5 (Stuiver et al. (1998).

At the base, a sand layer (unit 5). The upper part of unit 5 has been radiocarbon dated to $3630 \pm 30$ BP (Table 1).

\subsection{Vegetation and lake-level changes}

The results of pollen and sediment analysis from core 5 are presented in Figs. 3 and 4. The main features of vegetation history are consistent with regional pollen stratigraphy of the late Holocene as established for the northern French Pre-Alps (Beaulieu (de) et al., 1994).

Sediments of units 5-3 accumulated during the Subboreal pollen zone characterised by the domination of Quercus and Fagus, while the representation of Abies ranges from $7 \%$ to $22 \%$. Above level $88 \mathrm{~cm}$, an expansion of Fagus correlates with a decrease in Quercus and a stronger representation of Fraxinus, which attains 5\% at level $70 \mathrm{~cm}$. Except for level $48 \mathrm{~cm}$ characterised by a peak in Poaceae (archaeological layer), the pollen diagram does not show strong human impact on vegetation. Plantago lanceolata is present regularly between levels 108 and $88 \mathrm{~cm}$ and levels 62 and $44 \mathrm{~cm}$, where Cerealia displays an irregular representation. Above $46 \mathrm{~cm}$, the deposits accumulated during the Subatlantic pollen zone and give evidence of nearly similar landscapes. Fraxinus slightly develops between levels 42 and $32 \mathrm{~cm}$ and reaches ca. $6 \%$. The uppermost levels $(20,16$ and $8 \mathrm{~cm})$ probably reflect anthropogenic disturbances of the vegetation with correlative large variations in the representation of Quercus and Fagus. In core 6 (50 m away from core 5, Fig. 2), the continuous presence of Juglans observed in unit 1 suggests that unit 2 was deposited before the Roman period (Magny and Richard, 1985) and only documents the early Subatlantic pollen zone equivalent to the Iron Age. 


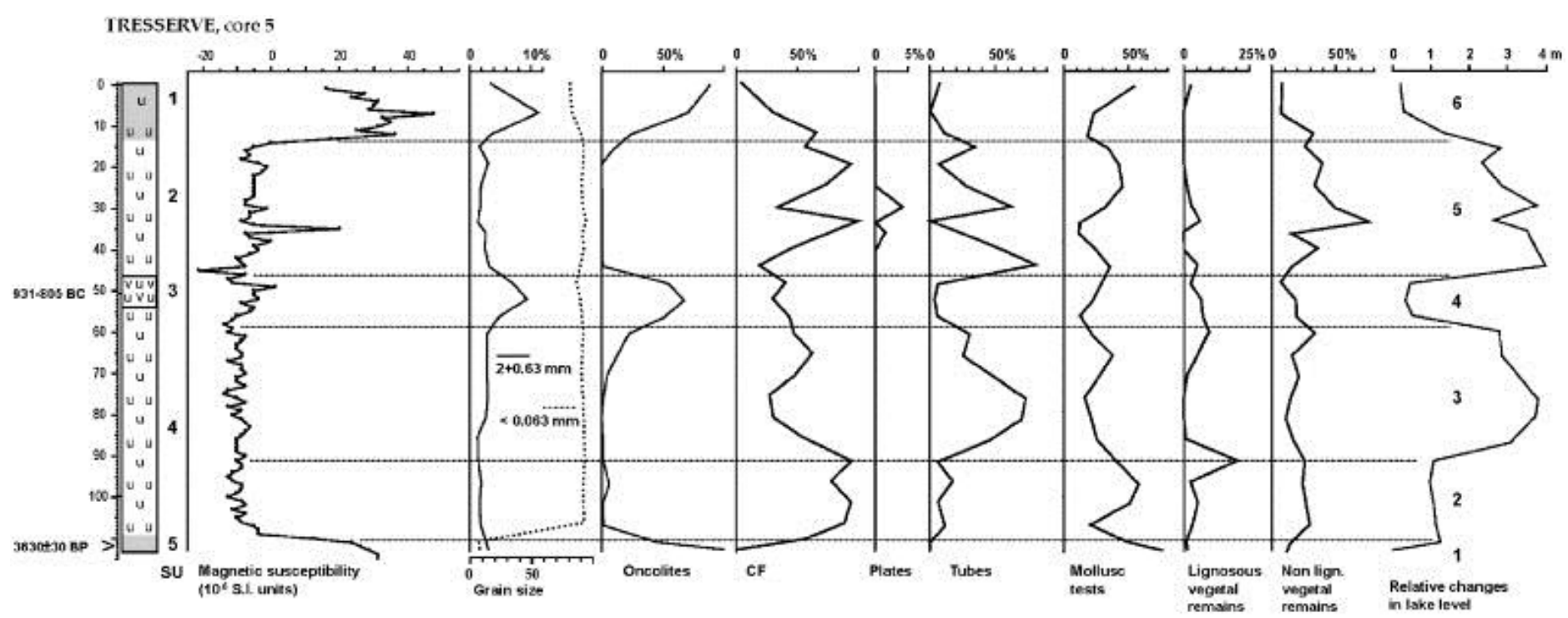

Fig. 4. Sedimentological diagram of core 5. SU: sediment units. The six successive phases of relative lake-level changes refer to Table 2 .

Table 2 summarises the 6 successive lake-level phases distinguished from the sediment analysis (Fig. 4). Considering the water-level fluctuations before modern times, peaks in oncolites mark major phases of low lake level at ca. $3800 \mathrm{cal} \mathrm{BP}$ and 931-805 BC.

Table 2. Sedimentological and lithologic markers used to reconstruct past variations in the water table at Tresserve

$\begin{gathered}\text { Sediment } \\ \text { unit }\end{gathered}$
1
2
3
4
4
5

Coarser texture, development of oncolites, small peaks of plate and tube concretion

Sedimentological and lithologic markers

Lake level phases

Finer texture, absence of oncolites alteration of peaks of tube concreations and $\mathrm{CF}$

Coarser texture, maximum of oncolites

4

Decrease in $\mathrm{CF}$, peak of tube concretions

Decrease in oncolites, maximum of $\mathrm{CF}$, slight development of tube concretions finer texture

CF: cauliflower-type concretions. 


\subsection{Quantitative reconstruction of climatic variables}

Seven climatic variables have been reconstructed (Rouèche, 2005): total annual precipitation (PANN), summer precipitation (PSUM), winter precipitation (PWIN), mean annual temperature (TANN), mean annual temperature of the coldest month (MTCO) and the warmest month (MTWA), and the growing degree days (GDD5, i.e. the sum of daily temperatures above $5{ }^{\circ} \mathrm{C}$ ). Due to relatively strong human impact on the vegetation evidenced by pollen data, levels 20,16 and $8 \mathrm{~cm}$ of the sediment sequence have been not used for quantitative reconstructions of climatic parameters.

Fig. 5 presents the pollen and lake-level-based estimates of climatic variables obtained at Tresserve for the Bronze and early Iron Ages using the best analogue method (Guiot et al., 1993). Generally, the phases of higher lake level (3 and 5) correspond to decreasing MTCO and TANN, and increasing PANN and PSUM. The major phases of lower lake level (1-2 and 4), coincided with the opposite processes. The magnitude of the changes reaches ca. $0.8{ }^{\circ} \mathrm{C}$ for TANN, $1-1.2^{\circ} \mathrm{C}$ for MTCO, 70-100 mm for PANN, and 50-70 mm for PSUM. Unclear oscillation may be recognised from the PWIN curve. The MTWA and GDD5 curves give evidence of oscillations, which, although not statistically significant, are consistent with the information provided by the MTCO and TANN curves, i.e. a coincidence of high lake-level conditions with a decrease in MTWA by ca $1^{\circ} \mathrm{C}$ and in GDD5 by ca 200 days with a temperature greater than $5^{\circ} \mathrm{C}$. 


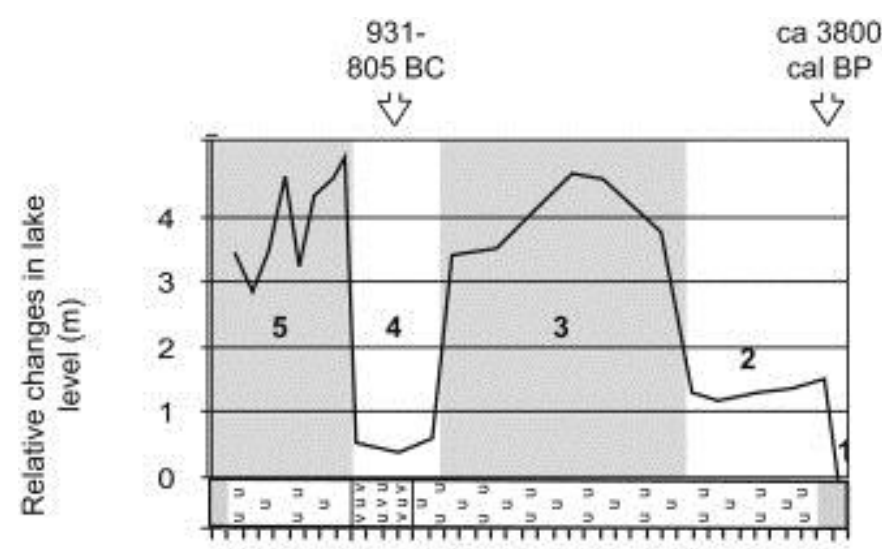

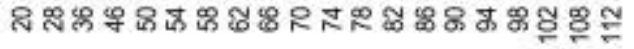
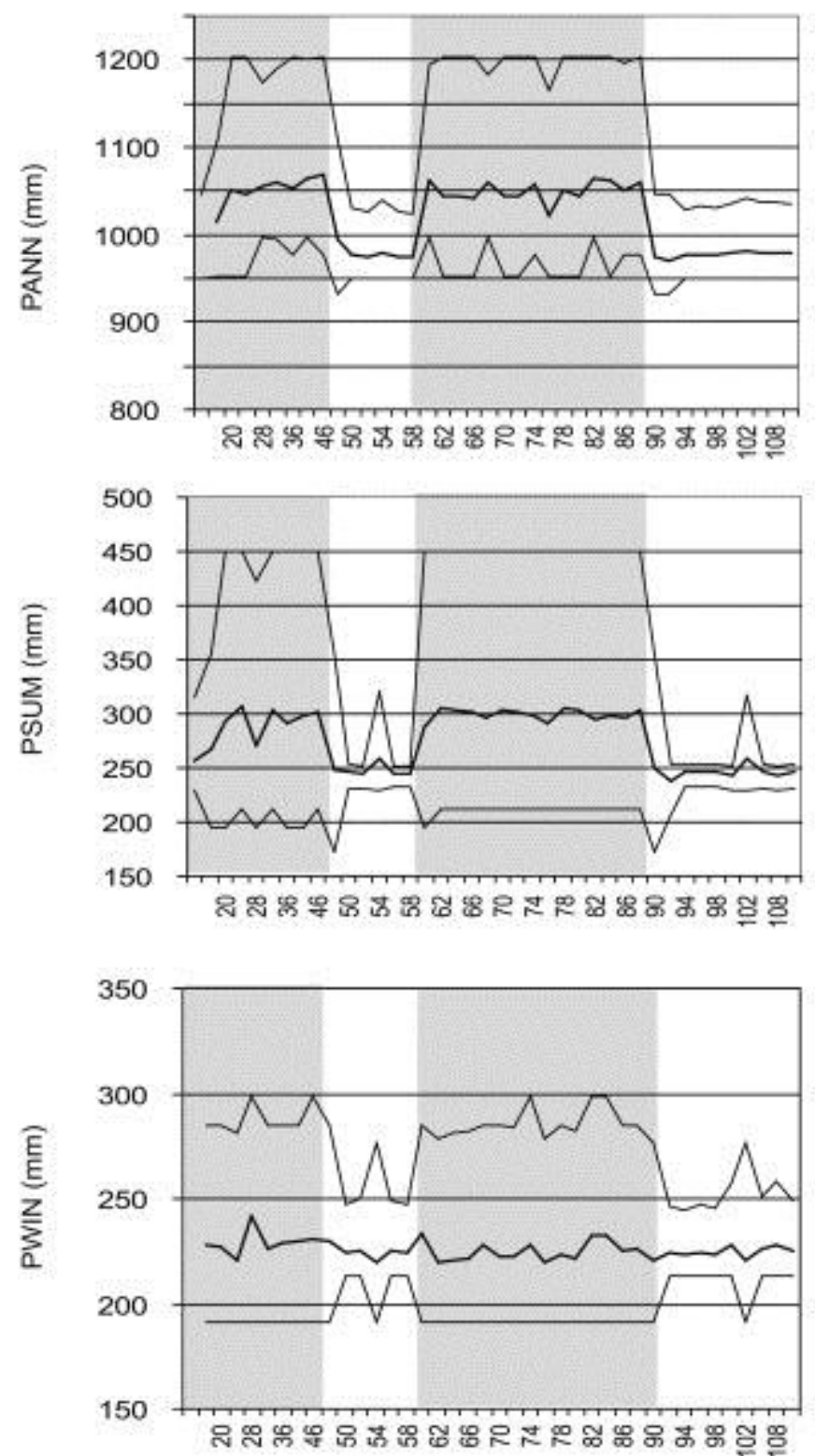

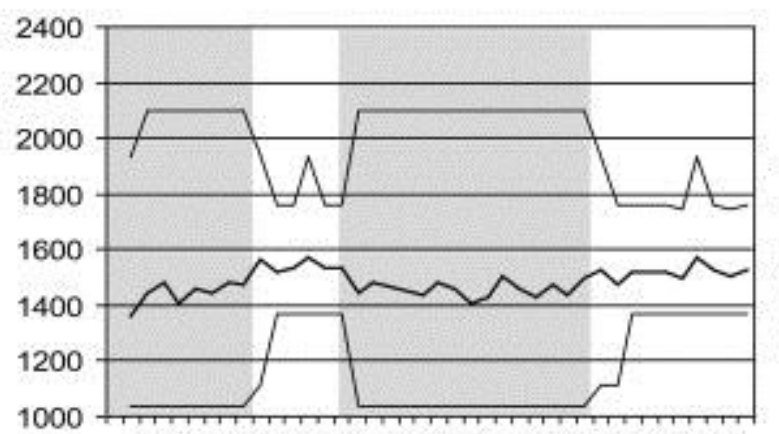

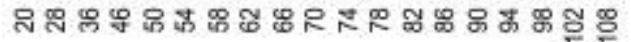
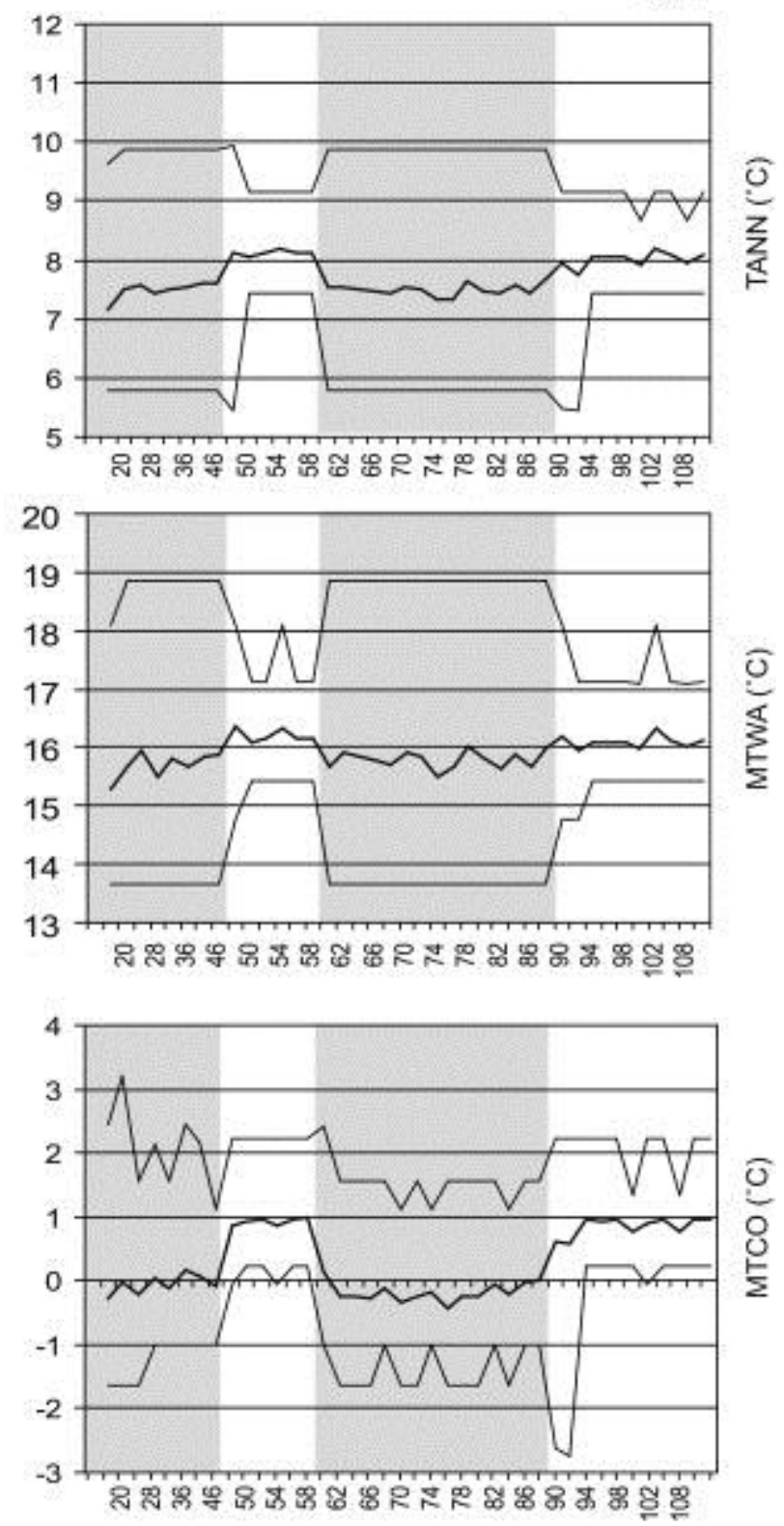

Fig. 5. Climatic parameters with confidence interval reconstructed from core 5

(Rouèche, 2005). MTWA: mean temperature of the warmest month, MTCO: mean temperature of the coldest month, TANN: mean annual temperature, GDD5: growing 
degrees above $5{ }^{\circ} \mathrm{C} \times$ days, PANN: annual precipitation, PWIN: winter precipitation, PSUM: summer precipitation.

\section{Discussion and conclusions}

The vegetation and lake-level changes reconstructed at Tresserve, Lake Le Bourget, and their translation into quantitative climatic variables, offer the opportunity to examine the climatic variations which punctuated the Bronze and early Iron Ages in eastern France. The palaeohydrological changes recognised at Tresserve appear fully consistent with the regional pattern established for west-central Europe with phases of higher lake levels at 3500-3100 and 2750-2350 cal BP (and the correlative abandonment of lake-dwellings at ca. 1500 and 800 BC, i.e. 3450 and 2750 cal BP; Magny, 1993 and Magny, 2004; Magny et al., 2007) in relation to solar-forced climatic oscillations (van Geel et al., 1996; van Geel and Magny, 2002; Magny, 2004 and Magny, 2006). Using a combination of seismic investigations and sediment cores from the profundal zone of Lake Le Bourget, Chapron et al. (2005) identified a period of enhanced Rhone River flooding activity at ca. 2800 cal BP, synchronous with glacier advances in the Mont Blanc massif (Deline and Orombelli, 2005). Cooler and/or wetter climate conditions may have also favoured the expansion of Fagus observed above level $88 \mathrm{~cm}$ in the Tresserve pollen record and Fraxinus at levels 70 and 36-32 cm (Fig. 3).

van Geel et al. (1996) have shown that the climate cooling at ca. 2800 cal BP was a global event, which affected various regions in both hemispheres. The climate reversal dated to ca. $3500 \mathrm{cal}$ BP and marked by higher lake-level conditions in west-central Europe also seems to be a major climatic oscillation. While it coincided with a maximum in the residual atmospheric ${ }^{14} \mathrm{C}$ content (Stuiver et al., 1998) and in the Greenland ${ }^{10} \mathrm{Be}$ record (Bond et al., 2001), it also appears synchronous with an IRD event in the North Atlantic Ocean (Bond et al., 2001), a decrease in sea surface temperature of the Norwegian Sea (Birks and Koç, 2002; Calvo et al., 2002), a change in the North Atlantic Ocean circulation (Hall et al., 2004), a glacier advance in Iceland (Jiang et al., 2002) and in the Swiss and the Austrian Alps (Patzelt, 1977; Zoller, 1977; Haas et al., 1998), a decline in tree-limit in Austrian Alps (Nicolussi et al., 2005), and a reinforcement of humidity in mires and of discharge in rivers of England (Hughes et al., 2000; Macklin and Lewin, 2002). Moreover, a well marked climate cooling dated to 3500-3300 cal BP in Antarctica (Noon et al., 2003) suggests that the 3500 cal BP event may have affected both hemispheres.

When considering the quantitative estimates of seasonal changes in temperature and precipitation (Fig. 5), they appear consistent with environmental changes observed in westcentral Europe: temperature cooling and increasing precipitation at ca. 3500 and $2800 \mathrm{cal}$ BP may explain higher lake levels in the Jura Mountains and on the Swiss Plateau, and glacier advances and decline in tree-limit in the Alps. They are also consistent with values estimated from other proxies (Bortenschlager, 1977; Patzelt, 1985; Grafenstein (von) et al., 1994; Haas et al., 1998).

In regard to the possible impact of climate oscillations on Bronze and Iron Age communities, the Tresserve palaeoclimatic record suggests an influence of the climate not just for the location of their villages, but also on their socio-economic equilibrium. Phases of cooler and wetter climatic conditions may have provoked harvest failures, more particularly due to wetter summers. In agreement with the quantitative estimates of climatic variables reconstructed in this study, Tinner et al. (2003) have also pointed to the fact that, during climate reversals, an increase in precipitation probably had a more decisive impact than a temperature decrease on 
former settlements in marginal elevated areas like the Alps. Likewise, in Germany, Zolitschka et al. (2003) observed that from the Bronze Age to the Migration period, there are reasons to assume that, at least within the margin of error in the dating methods used, a coincidence appears between phases of unfavourable climatic conditions (cool and moist) and a decrease in human activities.

However, archaeological data collected in the Jura region (eastern France) invites to rule out an excessive deterministic view of human history, at least from a regional point of view (Gauthier, 2001). Fig. 6 presents curves based on the chronological distribution of archaeological sites recognised in the region of Franche-Comte from the mid-Neolithic to the early Iron Age (Pétrequin et al., 2005). The left-hand curve includes all sites while the righthand curve excludes sites in humid areas such as lake shores and karstic caves. A comparison of these archaeological data with the regional pattern of climate changes as reflected by lakelevel fluctuations, indicates a stronger impact of climatic conditions on prehistoric societies during the Neolithic, especially at ca. 5500 and 4850 cal BP, than during the Bronze and early Iron Ages. The curve including sites in humid areas, more sensitive to changes in climate conditions, also shows marked variations, which mainly reflect the development of late Bronze Age lake-dwellings and their abandonment at ca. 2800 cal BP. However, the righthand curve, which excludes sites in humid areas, shows a general trend toward an increasing population density from 3500 to $2400 \mathrm{cal} \mathrm{BP}$. This is in agreement with increasing anthropogenic disturbances observed in regional pollen diagram for the same period (Richard, 1994 and Richard, 1995; Richard and Gauthier, 2007). In contrast, the period 4200$3500 \mathrm{cal}$ BP appears characterised by a general decrease in population density, which cannot be simply attributed to a climatic reversal which was limited to 4150-3950 cal BP. Such observations invite caution when proposing general interpretations from single sites and suggest progress in the relative emancipation of protohistoric societies from climatic conditions. Such progress probably reflects the spread of new modes of social and economic organisation (Pétrequin et al., 2005). 


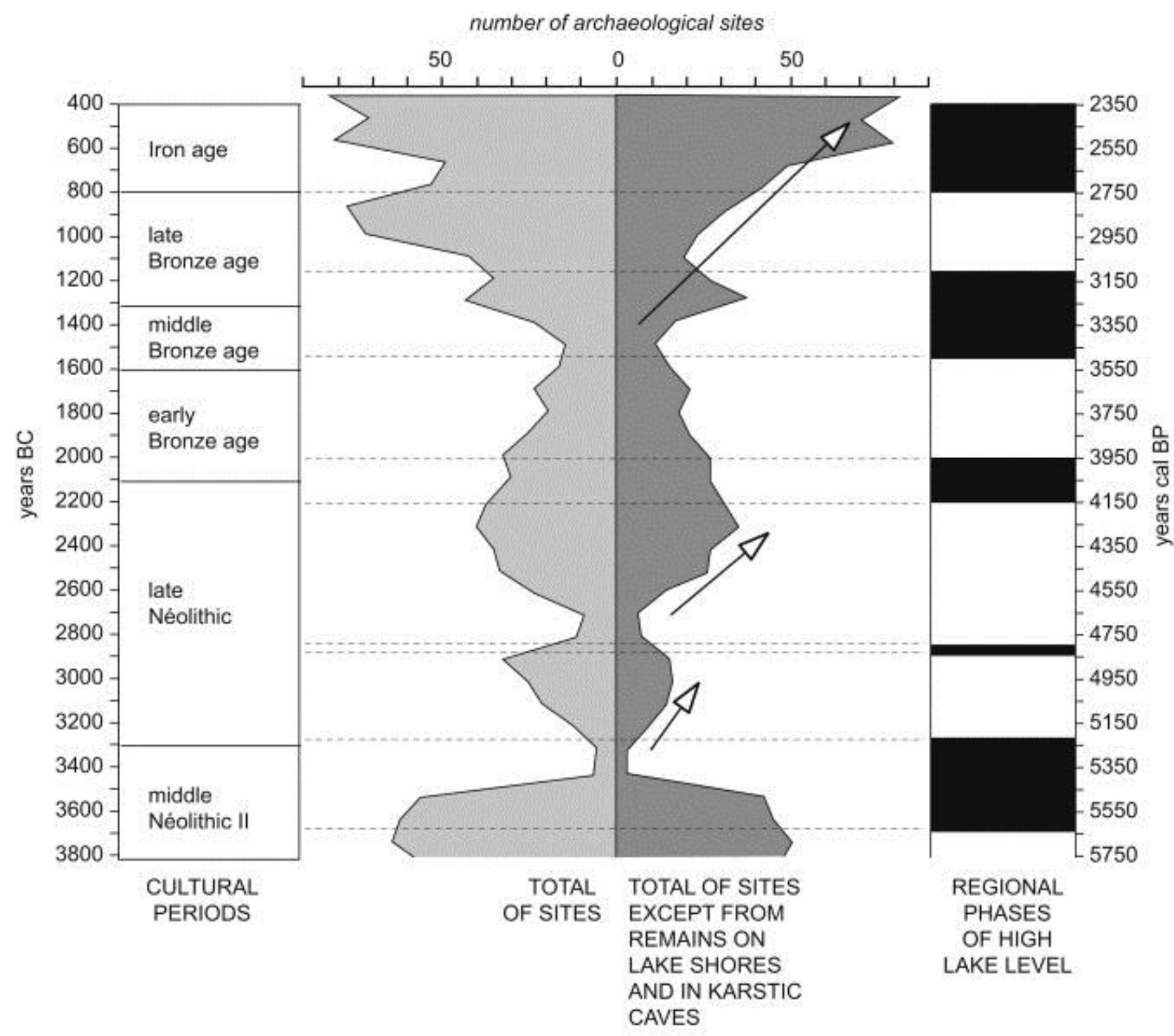

Fig. 6. Comparison between the regional pattern of variations in climate as reflected by lake-level fluctuations (Magny, 2004 and Magny, 2006) and changes in population density inferred from the number of archaeological sites in the region Franche-Comte, eastern France (Pétrequin et al., 2005). The left-hand curve includes all sites while the right-hand curve excludes sites in humid areas such as lake shores and karstic caves.

\section{Acknowledgements}

Financial support for this study was provided by the French CNRS (Programme Environnement et Climats du Passé) and by the EU (ACCROTELM project, under the leadership of F. Chambers). The authors express their sincere thanks to John Olsen for his help with the English language. 


\section{References}

J.-L. Beaulieu (de), H. Richard, P. Ruffaldi, J. Clerc

History of vegetation, climate and human action in the French Alps and the Jura over the last 15,000 years

Dissertationes Botanicae, 234 (1994), pp. 253-276

Y. Billaud

L'organisation architecturale des stations Bronze final du lac du Bourget (Savoie) : résultats récents à Conjux/Le Port 3

Bulletin Société Préhistorique Française, 1 (2006), pp. 167-171

Y. Billaud, A. Marguet

Les établissements littoraux des grands lacs alpins français. Dans : Hafner A. \& al. (dir) Une nouvelle interprétation de l'histoire : l'apport de l'archéologie subaquatique

Archéologie suisse, 40 (2006), pp. 70-74

C. Birks, N. Koç

A high-resolution diatom record of late-Quaternary sea-surface temperatures and oceanographic conditions from the eastern Norwegian Sea

Boreas, 31 (2002), pp. 323-344

G. Bond, B. Kromer, J. Beer, R. Muscheler, M.N. Evans, W. Showers, S. Hoffmann, R. LottiBond, I. Hajdas, G. Bonani

Persistent solar influence on North Atlantic climate during the Holocene

Science, 294 (2001), pp. 2130-2136

S. Bortenschlager

Ursachen and ausmass postglazialer waldgrenzschwankungen in den Ostalpen

B. Frenzel (Ed.), Dendrochronologie und Postglaziale Klimaschwankungen in Europa, Steiner, Wiesbaden (1977), pp. 260-266

E. Calvo, J. Grimalt, E. Jansen

High resolution Uk/37 sea surface temperature reconstruction in the Norwegian Sea during the Holocene

Quaternary Science Reviews, 21 (2002), pp. 1385-1394

E. Chapron, F. Arnaud, H. Noël, M. Revel, M. Desmet, L. Perdereau

Rhone river flood deposits in lake le bourget: a proxy for Holocene environment changes in the NW Alps, France

Boreas, 34 (2005), pp. 404-416

R. Cheddadi, G. Yu, J. Guiot, S.P. Harrison, I.C. Prentice

The climate 6000 years ago in Europe

Climate Dynamics, 13 (1997), pp. 1-9

P. Deline, G. Orombelli

Glacier fluctuations in the western Alps during the Neoglacial, as indicated by the Miage morainic amphitheater (Mont Blanc massif, Italy)

Boreas, 34 (2005), pp. 456-467 
Gauthier, E., 2001. Evolution de l'impact de l'homme sur la végétation du massif jurassien au cours des quatre derniers millénaires. Nouvelles données palynologiques. Ph.D., Université de Franche-Comté, p. 250.

U. Grafenstein (von), H. Erlenkeuser, A. Kleinmann, J. Müller, P. Trimborn

High-frequency climatic oscillations during the last deglaciation as revealed by oxygen-isotope records of benthic organisms (Ammersee, southern Germany) Journal of Paleolimnology, 11 (1994), pp. 349-357

J. Guiot, S.P. Harrison, I.C. Prentice

Reconstruction of Holocene pattern of moisture in Europe using pollen and lakelevel data

Quaternary Research, 40 (1993), pp. 139-149

J.N. Haas, I. Richoz, W. Tinner, L. Wick

Synchronous Holocene climatic oscillations recorded on the Swiss Plateau and at Timberline in the Alps

The Holocene, 8 (1998), pp. 301-304

I.R. Hall, G.G. Bianchi, J.R. Evans

Centennial to millennial scale Holocene climate-deep water linkage in the North Atlantic

Quaternay Science Reviews, 23 (2004), pp. 1529-1536

O. Heiri, A.F. Lotter, S. Hausmann, F. Kienast

A chironomid-based Holocene summer air temperature reconstruction from the Swiss Alps

The Holocene, 13 (2003), pp. 477-484

P.D.M. Hughes, D. Mauquoy, K.E. Barber, P.G. Langdon

Mire-development pathways and palaeo-climatic records from a full Holocene peat archive at Walton Moss, Cumbria, England

The Holocene, 10 (2000), pp. 465-479

H. Jiang, M.-S. Seidenkranz, K.L. Knudsen, J. Eiriksson

Late-Holocene summer sea-surface temperatures based on a diatom record from the north Icelandic shelf

The Holocene, 12 (2002), pp. 137-147

M.G. Macklin, J. Lewin

River sediments, great floods and centennial-scale Holocene climate change

Journal of Quaternary Science, 18 (2002), pp. 101-105

M. Magny

Climatic contribution can provide an answer for prehistoric lake dwellings

Compte-Rendus Académie des Sciences Paris, 316 (1993), pp. 1619-1625

M. Magny

Reconstruction of Holocene lake-level changes in the Jura (France): methods and results

Paläoklimaforschung, 25 (1998), pp. 67-85 
Holocene climatic variability as reflected by mid-European lake-level fluctuations, and its probable impact on prehistoric human settlements

Quaternary International, 113 (2004), pp. 65-79

M. Magny

Holocene Fluctuations of Lake Levels in West-Central Europe: Methods of

Reconstruction, Regional Pattern, Palaeo-climatic Significance and Forcing

Factors. Encyclopedia of Quaternary Geology

Elsevier, Amserdam (2006) pp. 1389-1399

M. Magny, Y. Billaud, G. Bossuet, E. Gauthier, A. Marguet, J. Mouthon, H. Richard, B. Vannière

Variations du climat pendant l'Age du Bronze au centre ouest de l'Europe: vers l'établissement d'une chronologie à haute rèsolution

H. Richard, M. Magny, C. Mordant (Eds.), Environnements et cultures à l'Age du Bronze en Europe occidentale, Editions CTHS, Paris (2007), pp. 13-28

M. Magny, H. Richard

Contribution à l'histoire holocène du lac du Bourget: recherches

sédimentologiques et palynologiques sur le site de Conjux-la-Chatière (Savoie, France)

Revue de Paléobiologie, 4 (1985), pp. 253-277

M. Magny, J. Guiot, P. Schoellammer

Quantitative reconstruction of younger dryas to mid-Holocene paleoclimates at Le Locle, Swiss Jura, using pollen and lake-level data

Quaternary Research, 56 (2001), pp. 170-180

Marguet, A., 1995. Le Néolithique des lacs alpins français. Bilan documentaire. In: Voruz, J.L. (Ed.), Chronologies néolithiques. Société Préhistorique Rhodanienne, Ambérieu-enBugey, pp, 167-196

Marguet, A., Billaud, Y., 1997. Géoarchéologie subaquatique dans les lacs alpins français. In: Bravard, J.P., Prestreau, M. (Eds.), Dynamique du paysage. Entretiens de Géoarchéologie. Documents d'Archéologie en Rhône-Alpes, pp. 199-264.

J.P. Millotte

Le Jura et les plaines de la Saône aux âges des métaux

Annales Littéraires de l’Université de Besançon, 59 (1963), p. 452

K. Nicolussi, M. Kaufmann, G. Patzelt, J. van der Plicht, A. Thurner

Holocene tree-line variability in the Kauner valley, central-eastern Alps, indicated by dendrochronological analysis of living trees and subfossil logs

Vegetation History and Archaeobotany, 14 (2005), pp. 221-234

P.E. Noon, M.J. Leng, V.J. Jones

Oxygen-isotope (d180) evidence of Holocene hydrological changes at Signy

Island, maritime Antarctica

The Holocene, 13 (2003), pp. 251-263

G. Patzelt 
Der zeitliche Ablauf und das Ausmass postglazialer Klimaschwankungen in den Alpen

B. Frenzel (Ed.), Dendrochronologie und Postglaziale Klimaschwankungen in Europa, Steiner, Wiesbaden (1977), pp. 248-259

G. Patzelt

The period of glacier advances in the Alps, 1965-1980

Zeitschrift für Gletscherkunde and Glazialgeologie, 21 (1985), pp. 403-407

Pétrequin, P., Magny, M., Bailly, M., 2005. Habitat lacustre, densité de population et climat. L'exemple du Jura français. In: Della Casa, P., Trachsel, M. (Eds.), WES'O4, Wetland Economies and Societies. Proceedings of the International Conference in Zürich, 10-13 March 2004. Collectio Archaeologica 3, pp. 140-168.

H. Richard

Evaluation de l'impact anthropique de l'homme sur la végétation : l'apport de la palynologie

Histoire et Mesure, 9 (1994), pp. 305-316

H. Richard

Indices d'anthropisation dansles diagrammes polliniques du massif jurassien Palynosciences, 3 (1995), pp. 37-49

H. Richard, E. Gauthier

Bilan des données polliniques concernant l'âge du Bronze dans le Jura et le nord des Alpes

H. Richard, M. Magny, C. Mordant (Eds.), Environnements et cultures à l'Age du Bronze en Europe occidentale, Editions CTHS, Paris (2007), pp. 71-88

H. Rouèche

Quantification de svariations climatiques dans le Jura méridional pendant l'âge du Bronze à partir de données polliniques et de niveaux lacustres. Master 2 Université de Franche-Comté (2005) p. 30

R. Schmidt, K.A. Koinig, R. Thompson, C. Kamekik

A multi proxy core study of the last 7000 years of climate and alpine land-use impacts on an Austrian mountain lake (Unterer Landschitzsee, Niedere Tauern) Palaeogeography, Palaeoclimatology, Palaeoecology, 187 (2002), pp. 101-120

Smolla, G., 1954. Der "Klimasturz" um 800 v. Chr. Und seine Bedeutung für die Kulturentwicklung in Süddeutschland. Festschrift f. Peter Gössler, Stuttgart, pp. 168-174.

M. Stuiver, P.J. Reimer, E. Bard, J.W. Beck, G.S. Burr, K.A. Hughen, B. Kromer, G.

McCormac, J. van der Plicht, M. Spurk

Intcal98 radiocarbon age calibration, 24,000-0 cal BP

Radiocarbon, 40 (1998), pp. 1041-1083

W. Tinner, A.F. Lotter, B. Ammann, M. Conedera, P. Hubschmid, J.F.N. van Leeuwen, M. Wehrli 
Climatic change and contemporaneous land-use phases north and south of the Alps $2300 \mathrm{BC}$ to $800 \mathrm{AD}$

Quaternary Science Reviews, 22 (2003), pp. 1447-1460

B. van Geel, M. Magny

Mise en évidence d'un forçage solaire du climat à partir de données paléoécologiques et archéologiques: la transition Subboréal-Subatlantique H. Richard, A. Vignot (Eds.), Equilibres et Ruptures dans les écosystèmes Depuis 20,000 ans en Europe de l'Ouest, vol. 730Annales Littéraires de l'Université de Franche-Comté (2002), pp. 107-122

B. van Geel, J. Buurman, H.T. Waterbolk

Archaeological and palaeoecological indications of an abrupt climate change in The Netherlands, and evidence for climatological teleconnections around $2650 \mathrm{BP}$ Journal of Quaternary Science, 11 (1996), pp. 451-460

B. Zolitschka, K.E. Behre, J. Schneider

Human and climatic impact on the environment as derived from colluvial, fluvial and lacustrine archives - examples from the Bronze Age to the migration period, Germany

Quaternary Science Reviews, 22 (2003), pp. 81-100

H. Zoller

Alter und Ausmass postglazialer Klimaschwankungen in den Schweizer Alpen B. Frenzel (Ed.), Dendrochronologie und Postglaziale Klimaschwankungen in Europa, Steiner, Wiesbaden (1977), pp. 271-281 